\section{Cross-sensitivity in Sweet Corn to Nicosulfuron and Mesotrione Applied Postemergence}

\author{
Martin M. Williams, II \\ United States Department of Agriculture-Agricultural Research Service, Invasive \\ Weed Management Research, University of Illinois, Urbana, IL 61801
}

Jerald K. Pataky, Jonathan N. Nordby, and Dean E. Riechers

Department of Crop Sciences, University of Illinois, Urbana, IL 61801

\section{Christy L. Sprague \\ Department of Crop and Soil Science, Michigan State University, East Lansing, MI 48824}

\section{John B. Masiunas \\ Department of Natural Resources and Environmental Sciences, University of Illinois, Urbana, IL 61801}

Additional index words. cultivar sensitivity, cytochrome P450, herbicide sensitivity, herbicide tolerance, Zea mays

\begin{abstract}
Nicosulfuron and mesotrione are herbicides from different chemical families with different modes of action. An association between the sensitivity of sweet corn (Zea mays L.) to nicosulfuron and mesotrione was observed when hybrids, inbreds, and $S_{1}$ families $\left(S_{2}\right.$ plants) were evaluated for herbicide sensitivity in field trials. In 2003 and 2004, 50\% and 53\% of mesotrione-sensitive hybrids were sensitive to nicosulfuron compared with only $6 \%$ and $1 \%$ of mesotrione-tolerant hybrids that were sensitive to nicosulfuron. In trials with inbreds in 2003 and $2004,88 \%$ and $78 \%$ of nicosulfuron-sensitive inbreds had some injury from mesotrione but $0 \%$ and $5 \%$ of nicosulfuron-tolerant inbreds were injured by mesotrione. Among $\mathrm{S}_{1}$ families, $\mathbf{7 7 \%}$ of the mesotrione-sensitive families were nicosulfuron-sensitive but only $5 \%$ of the mesotrione-tolerant families were sensitive to nicosulfuron. Segregation of $S_{1}$ families for response to mesotrione was not significantly different from a 1:2:1 pattern of sensitive: segregating: tolerant families (chi square value $=\mathbf{2 . 2 5}, P=0.324$ ) which would be expected if sensitivity was conditioned by a single recessive gene. Segregation of $S_{1}$ families for response to nicosulfuron was $15: 23: 26$ (sensitive: segregating: tolerant) which was slightly different from an expected 1:2:1 ratio (chi square value $=8.84, P=0.012$ ). Segregation of $S_{1}$ families probably was affected by the relatively small number of $S_{2}$ plants sampled from each family. Similar responses of the $S_{1}$ families to nicosulfuron and mesotrione lead us to hypothesize that the same recessive gene is conditioning sensitivity to both herbicides. Possibly, this gene is common in the inbreds and hybrids that were sensitive in these trials. These hypotheses will be tested by examining segregation in $\mathrm{S}_{2}$ families and other segregating generations and by conducting tests of allelism among sensitive inbreds and inbred parents of sensitive hybrids. Chemical names: 2-(4-mesyl-2-nitrobenzoyl)-3-hydroxycyclohex-2-enone, (mesotrione); 2-[[[[(4,6-dimethoxy-2-pyrimidinyl)amino]carbonyl]amino]sulfonyl]-N,Ndimethyl-3-pyridinecarboxamide, (nicosulfuron).
\end{abstract}

Nicosulfuron and mesotrione are postemergence herbicides labeled for weed control in sweet corn (Zea mays L.), but their use is restricted by injury to corn. Certain sweet corn

\footnotetext{
Received for publication 22 Feb. 2005. Accepted for publication 14 May 2005. The authors greatly appreciate the encouragement and advice of Loyd M. Wax, George W. Crookham, and Patrick R. Mosely who initially proposed that we examine the response of these sweet corn lines to postemergence herbicide application. A portion of this research was supported by funding from the Midwest Food Processors Association, Crookham Company, and Illinois Foundation Seeds, Inc. Mention of a trademark, proprietary product, or vendor does not constitute a guarantee or warranty of the product by the U.S. Dept. of Agriculture and does not imply its approval to the exclusion of other products or vendors that also may be suitable.
}

hybrids and inbreds can be severely injured by nicosulfuron (Morton and Harvey, 1992; Stall and Bewick, 1992); mesotrione also is known to injure some corn hybrids (Masiunas et al., 2004; O'Sullivan et al., 2002). Therefore, new sweet corn hybrids and inbreds are routinely evaluated for sensitivity to herbicides.

Sulfonylurea herbicides, such as nicosulfuron, inhibit the acetolactate synthase (ALS) enzyme in susceptible plants (Chaleff and Mauvais, 1984; Ray, 1984). Plants that rapidly metabolize sulfonylurea herbicides are tolerant, whereas plants that metabolize these herbicides slowly are sensitive (Sweetser et al., 1982). Nicosulfuron is hydroxylated by cytochrome P450 in corn as a Phase I detoxification reaction (Kreuz et al., 1996). Cytochrome P450 in corn also metabolizes herbicides in at least five other chemical families; however, the number of 4450 s involved and regulation of their levels of activity are not clearly understood (Barrett, 1995, 2000; Boldt et al., 1992). Corn has many different cytochrome P450 genes (Frey et al., 1995). Possibly, a few or even one P450 is primarily responsible for herbicide metabolism (Barrett, 1995, 2000).

Green and Ulrich (1993) observed that the sensitivity of field corn and sweet corn to three sulfonylurea herbicides (nicosulfuron, primisulfuron, and thifensulfuron) was conditioned by a single recessive gene. Kang (1993) reported that sensitivity to nicosulfuron in the field corn inbreds Mp313E and L688 was inherited as a single recessive gene which was designated as nsfl. Twenty-three other field corn inbreds also were sensitive to nicosulfuron. Widstrom and Dowler (1995) also observed that sensitivity to nicosulfuron was conditioned by a single recessive gene in the field corn inbred Ab18. Moreno et al. (1999) used maize B-A translocation stocks to map the $n s f 1$ gene to the short arm of chromosome 7. Similarly, Bradshaw et al. (1994) observed that sensitivity of the field corn inbred GA209 to bentazon was controlled by a single recessive gene or possibly by two recessive genes, ben 1 and ben 2. F1 hybrids from crosses of GA209 and bentazon-tolerant inbreds were tolerant despite minor injury. The ben 1 gene also conditioned sensitivity to nicosulfuron (Barrett et al. 1997). Green (1998) reported unpublished data for the inbred F2 that mapped a gene for sensitivity to another sulfonylurea herbicide, rimsulfuron, on the short arm of chromosome 5 .

Sensitivity to the sulfonylurea herbicides and possibly to bentazon can be eliminated by backcrossing sensitive inbreds with tolerant inbreds and selecting against the recessive gene that conditions sensitivity. Tolerant hybrids also could be produced if at least one tolerant inbred is used as a parent and gene action is completely dominant.

Mesotrione, which has been designated as a reduced-risk herbicide by the U.S. Environmental Protection Agency, is a member of a relatively new class of herbicide chemistry that targets the 4-hydroxyphenylpyruvate dioxygenase (HPPD) enzyme, (Lee et al., 1997; Mitchell et al., 2001). These herbicides disrupt carotenoid biosynthesis and often are called bleaching herbicides because leaves of sensitive plants turn white and symptoms develop more quickly in the presence of light (Pallett, 2000; Wichert et al., 1999). Corn is tolerant to mesotrione due to metabolism of the herbicide(Mitchell et al., 2001) and mesotrione potentially could control weeds resistant to ALS-inhibiting and triazine herbicides (Sutton et al., 2002).

The objective of this study was to determine if an association exists between sweet corn sensitivity to nicosulfuron and mesotrione applied postemergence. Understanding the relationship between injury from these two herbicides will help corn breeders identify sensitivity to these herbicides at early generations in the breeding programs and allow herbicide manufacturers to construct pesticide labels that adequately address the risks of using these chemicals. 


\section{Materials and Methods}

Over 500 sweet corn hybrids, inbreds, and $S_{1}$ families ( $S_{2}$ plants) were evaluated for responses to nicosulfuron and mesotrione in adjacent field trials at the University of Illinois Crop Sciences Research and Education Center, Urbana, Ill. The soil-type was a Flanigan silt-loam (fine montimorrillontic, mesic, Aquic Arguidoll). Three replications of 288 hybrids and two replicates of 375 hybrids were arranged in randomized complete block designs in 2003 and 2004, respectively. Trials with inbreds included two replicates of 34 and 32 inbreds in 2003 and 2004, respectively. Two replicates of $64 \mathrm{~S}_{1}$ families were evaluated in 2004. $S_{1}$ families were derived from a cross of two sweet corn inbreds; one tolerant and one sensitive to both mesotrione and nicosulfuron. In all trials, an experimental unit was a single $3.5-\mathrm{m}$ row with 12 to 18 plants.

Commercial formulations of herbicides were applied to one-half of each row when plants were at the four- to six-leaf stages. The other half of the row served as a nontreated control. Nicosulfuron was applied at $35 \mathrm{~g} \cdot \mathrm{ha}^{-1}$ a.i. with a $0.25 \%(\mathrm{v} / \mathrm{v})$ nonionic surfactant and $2.5 \%(\mathrm{v} / \mathrm{v})$ urea ammonium nitrate. Mesotrione was applied at $105 \mathrm{~g} \cdot \mathrm{ha}^{-1}$ a.i. with $1 \%(\mathrm{v} / \mathrm{v})$ crop oil concentrate. Within each year, herbicide treatments were applied on the same day using a compressed-air backpack sprayer equipped with $80^{\circ}$ flat-fan nozzles delivering $187 \mathrm{~L} \cdot \mathrm{ha}^{-1}$ of water at $262 \mathrm{kPa}$.

Plants were evaluated for symptoms of herbicide injury 7 and $21 \mathrm{~d}$ after application. Injury was rated visually, as a percentage of the nontreated control, for chlorotic and necrotic leaves (nicosulfuron) or stunting and chlorotic and bleached leaves (mesotrione). Injury ratings were averaged over replicates. Hybrids and inbreds were classified as having high, moderate, or low levels of injury if the mean injury rating was $\geq 20 \%, \geq 5 \%$ and $<20 \%$, or $<5 \%$, respectively. Criteria for classifying hybrids and inbreds as sensitive varied among trials due to different distributions of injury as depicted in Table 1. In 2003 when injury was relatively low (modes, medians, and third quartiles were $0 \%$ injury), hybrids and inbreds were classified as sensitive to nicosulfuron if injury was $\geq 15 \%$ for either rating; and hybrids and inbreds were classified as sensitive to mesotrione if injury was $\geq 5 \%$ for either rating. In 2004 when most hybrids had some injury (modes were 1 to $5 \%$ for hybrids and $6 \%$ to $10 \%$ for inbreds, and medians ranged from $1.5 \%$ to $8.8 \%$ ), hybrids and inbreds classified as sensitive had slightly higher levels of injury than in 2003. In 2004, hybrids and inbreds were classified as sensitive to nicosulfuron if injury was $\geq 20 \%$ for both ratings and as sensitive to mesotrione if injury was $\geq 20 \%$ for the mean of the two ratings. $S_{1}$ families were classified as sensitive, tolerant or segregating based on responses of $\mathrm{S}_{2}$ plants within $S_{1}$ families.

Data were analyzed separately for each experiment. Two hypotheses were tested with binomial tests of proportions: 1) the percentage of nicosulfuron-sensitive hybrids (inbreds or $\mathrm{S}_{1}$ families) differed between mesotrione-sensitive and mesotrione-tolerant hybrids (inbreds or $\mathrm{S}_{1}$ families) and 2) the percentage of mesotrione-sensitive hybrids (inbreds or $\mathrm{S}_{1}$ families) differed between nicosulfuron-sensitive and nicosulfuron-tolerant hybrids (inbreds or $\mathrm{S}_{1}$ families). $\mathrm{S}_{1}$ families also were tested by a $\mathrm{Chi}$ square test of goodness of fit to determine if segregation of sensitive: segregating: tolerant families fit a 1:2:1 pattern which would be expected if sensitivity was conditioned by a single recessive gene.

\section{Results}

In $2003,89 \%$ of the 288 hybrids tested were classified as tolerant to both herbicides (Table 2). In 2004, 97\% of the 375 hybrids tested were tolerant to both herbicides. Injury from nicosulfuron application exceeded $50 \%$ for hybrids and inbreds that were most sensitive, and some hybrids and inbreds were killed by nicosulfuron. Maximum injury from mesotrione application was 30\% in 2003 and $60 \%$ in 2004 , but no plants were killed by mesotrione.
In $2003,53 \%$ ( 8 of 15 ) of the mesotrionesensitive hybrids were sensitive to nicosulfuron compared with only 6\% (16 of 273) of the mesotrione-tolerant hybrids that were sensitive to nicosulfuron (Table 2). In 2004, 3 of 6 mesotrione-sensitive hybrids were sensitive to nicosulfuron but only $1 \%$ ( 5 of 369 ) of the mesotrione-tolerant hybrids were sensitive to nicosulfuron. Thirty-three percent ( 8 of 24) of the hybrids that were sensitive to nicosulfuron in 2003 also were sensitive to mesotrione, while only $3 \%$ ( 7 of 264 ) of the nicosulfuron-tolerant hybrids were sensitive to mesotrione. In 2004, $38 \%$ (3 of 8) of the hybrids sensitive to nicosulfuron also were sensitive to mesotrione but only $1 \%$ ( 3 of 367 ) of the nicosulfuron-tolerant hybrids were sensitive to mesotrione.

Hybrids injured by nicosulfuron and/or mesotrione application included shrunken-2, sugary enhancer, and normal sugary endosperm phenotypes from several different commercial sweet corn breeding programs (Table 3). There were no obvious associations between responses to herbicides and endosperm phenotype, kernel color, or other ear or plant characteristics that are typically important for sweet corn hybrids.

Asimilar association between sensitivity to nicosulfuron and mesotrione occurred among inbred lines. In 2003, 100\% (7 of 7) of the mesotrione-sensitive hybrids were sensitive to nicosulfuron compared with only $4 \%$ (1 of 27) of the mesotrione-tolerant hybrids that were sensitive to nicosulfuron (Table 4). In 2004, 7 of 8 mesotrione-sensitive hybrids were sensitive to nicosulfuron and 10\% (2 of 20) of the mesotrione-tolerant hybrids were sensitive to nicosulfuron. In total, $88 \%$ ( 7 of 8 ) of the nicosulfuron-sensitive inbreds had some injury from mesotrione in 2003 but none of the 26 nicosulfuron-tolerant inbreds were injured by mesotrione. In 2004, 78\% (7 of 9) of the nicosulfuron-sensitive inbreds were sensitive to mesotrione but only $5 \%$ ( 1 of 19$)$ of the nicosulfuron-tolerant inbreds were sensitive to mesotrione.

The association between sensitivity to mesotrione and nicosulfuron also was evident

Table 1. Distributions of sweet corn hybrids and inbreds for level of injury (\%) following postemergence applications of nicosulfuron or mesotrione herbicides in 2003 and 2004.

\begin{tabular}{|c|c|c|c|c|c|c|c|c|}
\hline \multirow{3}{*}{$\begin{array}{l}\text { Level of } \\
\text { injury }(\%)^{z}\end{array}$} & \multicolumn{4}{|c|}{ Hybrid } & \multicolumn{4}{|c|}{ Inbred } \\
\hline & \multicolumn{2}{|c|}{2003} & \multicolumn{2}{|c|}{2004} & \multicolumn{2}{|c|}{2003} & \multicolumn{2}{|c|}{2004} \\
\hline & Nicosulfuron & Mesotrione & Nicosulfuron & Mesotrione & Nicosulfuron & Mesotrione & Nicosulfuron & Mesotrione \\
\hline 0 & 156 & 207 & 70 & 132 & 24 & 27 & 6 & 6 \\
\hline 6 to 10 & $24^{* y, x}$ & $9^{*}$ & 86 & 58 & 0 & $6^{*}$ & 7 & 10 \\
\hline 11 to 15 & $5^{*}$ & $5^{*}$ & 33 & 18 & 0 & 0 & 0 & 0 \\
\hline 16 to 20 & $2^{*}$ & $1^{*}$ & 6 & 10 & 0 & 0 & 1 & 0 \\
\hline 21 to 30 & $2^{*}$ & 0 & $6^{*} \mathrm{w}$ & $4^{*}$ & 0 & $1^{*}$ & $3^{*}$ & $3^{*}$ \\
\hline $\mathrm{n}$ & 288 & 288 & 375 & 375 & 34 & 34 & 28 & 28 \\
\hline Mean & 3.5 & 0.9 & 6 & 3.9 & 14.6 & 1.7 & 22.3 & 2.4 \\
\hline Mode & 0 & 0 & $1 \%$ to $5 \%$ & $1 \%$ to $5 \%$ & 0 & 0 & $6 \%$ to $10 \%$ & $6 \%$ to $10 \%$ \\
\hline $1 \mathrm{Q}$ & 0 & 0 & 2.5 & 0 & 0 & 0 & 5 & 2.5 \\
\hline Median & 0 & 0 & 4 & 1.5 & 0 & 0 & 8.8 & 5 \\
\hline $3 \mathrm{Q}$ & 3.5 & 1 & 7.5 & 5 & 0 & 0 & 30 & 20.6 \\
\hline
\end{tabular}

${ }^{2}$ Level of injury was based on mean of ratings 7 and $21 \mathrm{~d}$ after application.

${ }^{y}$ An asterisk indicates that hybrids with these levels of injury were classified as sensitive (see text).

${ }^{\mathrm{x}}$ Seven of twenty-four hybrids were classified as sensitive based on injury $\geq 15 \%$ for one of the two ratings.

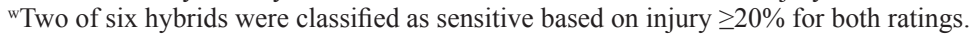


among $\mathrm{S}$ families. Seventy-seven percent (10 of 13) of the mesotrione-sensitive families were nicosulfuron-sensitive but only $5 \%$ ( 1 of 21 ) of the mesotrione-tolerant families were sensitive to nicosulfuron (Table 5). Likewise, 91\% (10 of 11) of the nicosulfuron-sensitive families were sensitive to mesotrione, but only $13 \%$

( 3 of 23) of the nicosulfuron-tolerant families were sensitive to mesotrione.

$\mathrm{S}_{1}$ families segregated for responses to each herbicide. All $\mathrm{S}_{2}$ plants in $13 \mathrm{~S}_{1}$ families were sensitive to mesotrione, and all $\mathrm{S}_{2}$ plants in $21 \mathrm{~S}_{1}$ families were tolerant to mesotrione (Table 6). In $30 \mathrm{~S}_{1}$ families, $\mathrm{S}_{2}$ plants segregated for me-

Table 2. Number of sweet corn hybrids with sensitive and tolerant responses to nicosulfuron and mesotrione in 2003 and $2004 .^{z}$

\begin{tabular}{|c|c|c|c|}
\hline \multirow{2}{*}{$\begin{array}{l}\text { Response to } \\
\text { nicosulfuron }\end{array}$} & \multicolumn{2}{|c|}{ Response to mesotrione } & \multirow{2}{*}{$\begin{array}{c}\text { Sensitive to } \\
\text { mesotrione }(\%)\end{array}$} \\
\hline & Sensitive & Tolerant & \\
\hline \multicolumn{4}{|l|}{2003} \\
\hline Sensitive & 8 & 16 & $33^{y}$ \\
\hline Tolerant & 7 & 257 & 3 \\
\hline Sensitive to nicosulfuron $(\%)$ & $53^{\mathrm{x}}$ & 6 & \\
\hline \multicolumn{4}{|l|}{2004} \\
\hline Sensitive & 3 & 5 & $38^{w}$ \\
\hline Tolerant & 3 & 364 & 1 \\
\hline Sensitive to nicosulfuron $(\%)$ & $50^{\mathrm{v}}$ & 1 & \\
\hline
\end{tabular}

${ }^{z}$ Classification based on mean plant response from injury ratings taken 7 and $21 \mathrm{~d}$ after herbicide application. yProbability of equal percentages of mesotrione-sensitive hybrids for nicosulfuron-sensitive and nicosulfuron-tolerant hybrids $P=0.0008$.

xProbability of equal percentages of nicosulfuron-sensitive hybrids for mesotrione-sesnitive and mesotrione-tolerant hybrids $P=0.0001$.

wProbability of equal percentages of mesotrione-sensitive hybrids for nicosulfuron-sensitive and nicosulfuron-tolerant hybrids $P=0.016$.

"Probability of equal percentages of nicosulfuron-sensitive hybrids for mesotrione-sesnitive and mesotrione-tolerant hybrids $P=0.0086$.

Table 3. Sweet corn hybrids injured by nicosulfuron and/or mesotrione applied postemergence in 2003 and 2004.

\begin{tabular}{|c|c|c|c|}
\hline Hybrid & Kernel color & Endosperm type & Seed source \\
\hline \multicolumn{4}{|c|}{ Injury from nicosulfuron and mesotrione $\geq 20 \%$} \\
\hline Kahuna & Yellow & Shrunken-2 & Snowy River \\
\hline Mystique & Bicolor & Sugary enhancer & Crookham \\
\hline SVR 08413005 & Yellow & Shrunken-2 & Seminis \\
\hline SVR 08705770 & White & Shrunken-2 & Seminis \\
\hline SVR 08705778 & White & Shrunken-2 & Seminis \\
\hline XTH 1172 & Yellow & Shrunken-2 & Illinois Foundation \\
\hline \multicolumn{4}{|c|}{ Injury from nicosulfuron and mesotrione $\geq 5 \%$} \\
\hline Argent & White & Sugary enhancer & Crookham \\
\hline Celestial & White & Synergistic sugary enhancer & Crookham \\
\hline Dynamo & Yellow & Sugary & Harris Moran \\
\hline E1 Toro & Yellow & Sugary & Seminis \\
\hline $\mathrm{SCH} 70064 \mathrm{R}$ & Yellow & Shrunken-2 & Illinois Foundation \\
\hline XTH 1171 & Yellow & Shrunken-2 & Illinois Foundation \\
\hline XTH 1279 & Yellow & Shrunken-2 & Illinois Foundation \\
\hline \multicolumn{4}{|c|}{ Injury from mesotrione $\geq 5 \%$ and $<20 \%$} \\
\hline $178 \mathrm{~A}$ & Yellow & Shrunken-2 & Illinois Foundation \\
\hline ACX 1079Y & Yellow & Shrunken-2 & Abbott and Cobb \\
\hline EX 8446457 & White & Sugary enhancer & Seminis \\
\hline Fantasia & White & Sugary enhancer & Seminis \\
\hline GH 2669 & Yellow & Sugary & Rogers/Syngenta \\
\hline Polaris & Bicolored & Shrunken-2 & Harris Moran \\
\hline SVR 08737068 & White & Shrunken-2,syn & Seminis \\
\hline XTH 1575 & Yellow & Shrunken-2 & Illinois Foundation \\
\hline \multicolumn{4}{|c|}{ Injury from nicosulfuron $\geq 5 \%$ and $<20 \%$} \\
\hline $170 \mathrm{~A}$ & Yellow & Shrunken-2 & Illinois Foundation \\
\hline Coho & Yellow & Sugary & Harris Moran \\
\hline CSHBF3-122 & Bicolored & Shrunken-2 & Crookham \\
\hline Double Gem & Bicolored & Sugary enhancer & Mesa Maize \\
\hline GH 0991 & Yellow & Sugary & Rogers/Syngenta \\
\hline GH 2298 & Yellow & Sugary & Rogers/Syngenta \\
\hline GH 6198 & Yellow & Sugary & Rogers/Syngenta \\
\hline GSS 8529 & Yellow & Shrunken-2 & Rogers/Syngenta \\
\hline HMX 1382 & Yellow & Sugary & Harris Moran \\
\hline Hollywood & Bicolored & Shrunken-2 & Seminis \\
\hline K3-1382 & Bicolored & Shrunken-2 & Sakata Seed \\
\hline MXH 11707 & Bicolored & Sugary enhancer & Mesa Maize \\
\hline Rival & Yellow & Sugary & Seminis \\
\hline SCH 86705 & Bicolored & Shrunken-2 & Illinois Foundation \\
\hline Supersweet Jubilee & Yellow & Shrunken-2 & Rogers/Syngenta \\
\hline Supersweet Jubilee Plus & Yellow & Shrunken-2 & Rogers/Syngenta \\
\hline SVR 98736093 & Yellow & Shrunken-2 & Seminis \\
\hline Winstar & Yellow & Shrunken-2 & Rogers/Syngenta \\
\hline
\end{tabular}

sotrione-tolerance and sensitivity. Segregation of $\mathrm{S}_{1}$ families for response to mesotrione was not significantly different from a 1:2:1 pattern of sensitive: segregating: tolerant families (chi square value $=2.25, P=0.324$ ). Segregation of $S_{1}$ families for response to nicosulfuron was 15:23:26 (sensitive: segregating: tolerant) which was different from a 1:2:1 ratio with a $1 \%$ probability of Type I error (chi square value $=8.84, P=0.012$ ). A 1:2:1 pattern of segregation of $\mathrm{S}_{1}$ family responses to nicosulfuron was expected based on previous reports that nicosulfuron sensitivity is conditioned by a single recessive gene, $n s f 1$ (Kang, 1993) or benl (Barrett et al., 1997). Considering the relatively small sample size (usually six or fewer $\mathrm{S}_{2}$ plants treated per experimental unit), it was not unusual to observe a larger number of tolerant $\mathrm{S}_{1}$ families and a lower number of segregating $\mathrm{S}_{1}$ families than expected, because there was a relatively high probability $(P=0.18$ when $\mathrm{n}=6$ ) that a homozygous recessive (i.e., sensitive) $\mathrm{S}_{2}$ plant was not included among the six plants treated per experimental unit.

\section{Discussion}

An association between sensitivity to nicosulfuron and mesotrione was evident among sweet corn hybrids, inbreds, and $\mathrm{S}_{1}$ families evaluated in field trials. Some sweet corn hybrids have been identified recently as sensitive to multiple herbicides applied postemergence, such as Del Monte 20-38 which was identified in separate trials as sensitive to herbicides from three different chemical families; mesotrione (O'Sullivan et al., 2002), bentazon (Diebold et al., 2004), and nicosulfuron (R.H. Teyker, Del Monte Foods USA, personal communication).

The association between sensitivity to nicosulfuron and mesotrione was most apparent among the $S_{1}$ families and inbreds. Seventyseven percent (10 of 13) of the mesotrione-sensitive $S_{1}$ families were nicosulfuron-sensitive and $91 \%$ (10 of 11$)$ of the nicosulfuron-sensitive $S_{1}$ families were sensitive to mesotrione. Likewise, $88 \%$ and $78 \%$ of the nicosulfuronsensitive inbreds were mesotrione-sensitive, and $100 \%$ and $88 \%$ of the mesotrione-sensitive inbreds were nicosulfuron-sensitive. The association between responses to the two herbicides may have been more evident among the $S_{1}$ families than among hybrids because the $S$ families were genetically more similar than the groups of hybrids evaluated. In addition to a recessive gene for nicosulfuron and mesotrione sensitivity that appeared to be segregating among the $\mathrm{S}_{1}$ families, other genes may influence metabolism of these herbicides. Genetic variation for these other factors is likely to be greater among hybrids than among the $\mathrm{S}_{1}$ families. Thus, the association between responses to mesotrione and nicosulfuron may have been less distinctive among hybrids than among the $\mathrm{S}_{1}$ families.

The association between responses to the two herbicides may have been more evident among inbreds than among hybrids because inbreds were homozygous for genes conferring herbicide sensitivity while hybrids could have 
been homozygous or heterozygous. The percentage of inbreds tolerant to both herbicides (76\% in 2003 and 64\% in 2004) was lower than the percentage of tolerant hybrids. This may be due solely to the inbreds and hybrids sampled in these trials; however, it also may be due to an enhanced ability to detect herbicide sensitivity in homozygotes. In accordance with this theory, other researchers (Green and Ulrich, 1993; Kang, 1993; Landi et al., 1989; Rowe et al., 1990) have observed that maize inbreds usually were more sensitive to herbicides than maize hybrids. Kang (1993) emphasized the need to evaluate both hybrids and inbreds in herbicide sensitivity trials.

Most hybrids (89\% in 2003 and $97 \%$ in 2004) were classified as tolerant to nicosulfuron and mesotrione although many hybrids evaluated in 2004 had $5 \%$ to $20 \%$ injury to these herbicides. Among the few sensitive hybrids, a high percentage were sensitive to both herbicides. The lack of a perfect correlation between hybrid responses to nicosulfuron and mesotrione may have been due to heterozygosity of genes affecting herbicide metabolism, especially if genes for tolerance are not completely dominant. Green and Ulrich (1993) and Kang (1993) observed that F1 plants with a tolerant and a sensitive parent (i.e., heterozygous for the $n s f 1$ gene) were tolerant to nicosulfuron (i.e., complete dominance). Alternatively, different response of hybrids to nicosulfuron and mesotrione may have occurred because different genes are responsible for sensitivity to each herbicide or because other environmental factors affected responses of hybrids to the herbicides. Barrett et al. (1995) observed differential response of the inbred B90 to bentazon and nicosulfuron while the inbred GA209 was sensitive to both herbicides presumably because two genes, ben 1 and ben2, affected metabolism of bentazon while a single gene, ben1, affected metabolism of nicosulfuron. In most evaluations of sweet corn hybrid responses to nicosulfuron, a range of quantitative responses

Table 4. Number of sweet corn inbreds with sensitive and tolerant responses to nicosulfuron and mesotrione in 2003 and 2004.

\begin{tabular}{|c|c|c|c|}
\hline \multirow{2}{*}{$\begin{array}{l}\text { Response to } \\
\text { nicosulfuron }\end{array}$} & \multicolumn{2}{|c|}{ Response to mesotrione } & \multirow{2}{*}{$\begin{array}{c}\text { Sensitive to } \\
\text { mesotrione }(\%)\end{array}$} \\
\hline & Sensitive & Tolerant & \\
\hline \multicolumn{4}{|l|}{2003} \\
\hline Sensitive & 7 & 1 & $88^{y}$ \\
\hline Tolerant & 0 & 26 & 0 \\
\hline Sensitive to nicosulfuron $(\%)$ & $100^{x}$ & 4 & \\
\hline \multicolumn{4}{|l|}{2004} \\
\hline Sensitive & 7 & 2 & $78^{w}$ \\
\hline Tolerant & 1 & 18 & 5 \\
\hline Sensitive to nicosulfuron $(\%)$ & $88^{v}$ & 10 & \\
\hline
\end{tabular}

${ }^{2}$ Classification based on mean plant response from injury ratings taken 7 and $21 \mathrm{~d}$ after herbicide application. yProbability of equal percentages of mesotrione-sensitive inbreds for nicosulfuron-sensitive and nicosulfuron-tolerant inbreds $P<0.0001$.

xProbability of equal percentages of nicosulfuron-sensitive inbreds for mesotrione-sensitive and mesotrione-tolerant inbreds $P<0.0001$

wProbability of equal percentages of mesotrione-sensitive inbreds for nicosulfuron-sensitive and nicosulfuron-tolerant inbreds $P<0.0001$.

vProbability of equal percentages of nicosulfuron-sensitive inbreds for mesotrione-sesnitive and mesotrione-tolerant inbreds $P<0.0001$.

Table 5. Number of $S_{1}$ families of sweet corn with sensitive and tolerant responses to nicosulfuron and mesotrione in 2004. ${ }^{z}$

\begin{tabular}{|c|c|c|c|}
\hline \multirow{2}{*}{$\begin{array}{l}\text { Response to } \\
\text { nicosulfuron }\end{array}$} & \multicolumn{2}{|c|}{ Response to mesotrione } & \multirow{2}{*}{$\begin{array}{c}\text { Sensitive to } \\
\text { mesotrione }(\%)\end{array}$} \\
\hline & Sensitive & Tolerant & \\
\hline Sensitive & 10 & 1 & $91^{\mathrm{y}}$ \\
\hline Tolerant & 3 & 20 & 13 \\
\hline Sensitive to nicosulfuron $(\%)$ & $77^{x}$ & 5 & \\
\hline
\end{tabular}

${ }^{\mathrm{z}}$ Classification based on mean plant response from injury ratings taken 7 and $21 \mathrm{~d}$ after herbicide application.

yProbability of equal percentages of mesotrione-sensitive $\mathrm{S}_{1}$ families for nicosulfuron-sensitive and nicosulfuron-tolerant $\mathrm{S}_{1}$ families $P<0.0001$.

xprobability of equal percentages of nicosulfuron-sensitive $S_{1}$ families for mesotrione-sensitive and mesotrione-tolerant $\mathrm{S}_{1}$ families $P<0.0001$.

Table 6. Number of $S_{1}$ families of sweet corn with sensitive, segregating, and tolerant responses to nicosulfuron and mesotrione. ${ }^{\mathrm{z}}$

\begin{tabular}{lcccc}
\hline Response to & \multicolumn{3}{c}{ Response to mesotrione } & Nicosulfuron \\
\cline { 2 - 5 } nicosulfuron & Sensitive & Segregating & Tolerant & total $^{\mathrm{y}}$ \\
\hline Sensitive & 10 & 4 & 1 & 15 \\
Segregating & 0 & 23 & 0 & 23 \\
Tolerant & 3 & 3 & 20 & 26 \\
Mesotrione total $^{\mathrm{x}}$ & 13 & 30 & 21 &
\end{tabular}

${ }^{\mathrm{z}}$ Classification based on response of $\mathrm{S}_{2}$ plants 7 and $21 \mathrm{~d}$ after herbicide application.

${ }^{\text {y }}$ Chi-square value $=8.84(P=0.012)$ for goodness of fit to a 1 sensitive $: 2$ segregating : 1 tolerant ratio for $\mathrm{S}_{1}$ family responses to nicosulfuron.

${ }^{x}$ Chi-square value $=2.25(P=0.325)$ for goodness of fit to a 1 sensitive : 2 segregating : 1 tolerant ratio for $\mathrm{S}_{1}$ family responses to mesotrione. has been observed (Grey et al., 2000; Morton and Harvey, 1992; O'Sullivan et al., 1995; O'Sullivan and Bouw, 1998; O'Sullivan et al., 2000; Robinson et al., 1994; Stall and Bewick, 1992). This range of response could be due to a combination of genetic and environmental factors affecting herbicide metabolism, including the possibility that plants heterozygous for $n s f 1$ or ben 1 metabolize nicosulfuron slower than plants that are homozygous dominant at either of these loci.

Sensitivity of sweet corn to nicosulfuron has been reported as being conditioned by a single recessive gene (Green and Ulrich, 1993; Kang, 1993; Widstrom and Dowler, 1995). In research reported here, segregation of $\mathrm{S}_{1}$ families for response to nicosulfuron was slightly different from the expected 1:2:1 ratio, however this probably is due to the small sample size of $\mathrm{S}_{2}$ plants treated. Larger sample sizes were not possible due to limited quantities of seed. Segregation of $\mathrm{S}_{1}$ families for response to mesotrione fit a 1:2:1 pattern, but these results should be confirmed in additional experiments with larger samples. The strong association between responses of the $\mathrm{S}_{1}$ families to nicosulfuron and mesotrione suggests that the same recessive gene may condition sensitivity to both herbicides. The genetic basis for the similarity of responses to these two herbicides will be examined further using $S_{2}$ families derived from the $S_{1}$ families evaluated in this work and using other segregating generations. Tests for allelism also are underway to determine if the same gene conditions herbicide sensitivity in other inbred lines that have been identified as nicosulfuron-sensitive (Green and Ulrich, 1993; Kang, 1993; Widstrom and Dowler, 1995) and in inbred lines that are parents of mesotrione-sensitive or nicosulfuron-sensitive sweet corn hybrids.

\section{Literature Cited}

Barrett, M. 1995. Metabolism of herbicides by cytochrome P450. Drug Metabolism Drug Interact. 12:299-315.

Barrett, M. 2000. The role of cytochrome P450 enzymes in herbicide metabolism, p. 25-37. In: A.H. Cobb and R.C. Kirkwood (eds.). Herbicides and their mechanisms of action. CRC Press, Boca Raton, Fla.

Barrett, M., L.D. Bradshaw, N.D. Polge, R.J. Baerg, and C.G. Poneleit. 1995. Evidence for multiple herbicide metabolizing cytochrome P450 from maize. Weed Sci. Soc. Amer. Abstr. 35:79.

Barrett, M., N. Polge, R. Baerg, R. Bradshaw, and C. Poneleit. 1997. Role of Cytochrome P450 in herbicide metabolism and selectivity and multiple herbicide metabolizing cytochrome P450 activities in maize, p. 35-50. In: K. Hatzios (ed.). Regulation of enzymatic systems detoxifying xenobiotics in plants. Kluwer Academic Publ., Dordrecht, Netherlands.

Boldt, L.D., M. Barrett, C.G. Poneleit, and N.D. Polge. 1992. Cytochrome P450 monooxygenase activity and cross-sensitivity to other herbicides of a bentazon-susceptible corn inbred. Weed Sci. Soc. Amer. Abstr. 32:185.

Bradshaw, L.D., M. Barrett, and C.G. Poneleit. 1994. Inheritance of bentazon susceptibility in a corn (Zea mays) line. Weed Sci. 42:641-647.

Chalef, R.S. and C.J. Mauvais. 1984. Acetolactate synthesis is the site of action of two sulfo- 
nylurea herbicides in higher plants. Science 224:1443-1445.

Diebold, S., D. Robinson, J.Zandstra, J. O'Sullivan, and P.H. Sikkema. 2004. Sweet corn sensitivity to bentazon. Weed Technol. 18:982-987.

Frey, M., R. Kliem, H. Saedler, and A. Gierl. 1995. Expression of a cytochrome P450 gene family in maize. Mol. Gen. Genet. 246:100-109.

Green, J.M. 1998. Differential tolerance of corn (Zea mays) inbreds to four sulfonlyurea herbicides and bentazon. Weed Technol. 12:474-477.

Green, J.M. and J.F. Ulrich. 1993. Response of corn (Zea mays L.) inbreds and hybrids to sulfonylurea herbicides. Weed Sci. 41:508-516.

Grey, T.L., D.C. Bridges, P. Raymer, D. Day, and D.S. NeSmith. 2000. Differential tolerance of fresh market sweet corn cultivars to the herbicides nicosulfuron and primisulfuron. HortScience 35:1070-1073.

Kang, M.S. 1993. Inheritance of susceptibility to nicosulfuron herbicide in maize. J. Hered. 84:216-217.

Krunz, K., R. Tommasini, and E. Martinoia. 1996. Old enzymes for a new job. Plant Physiol. 111:349-353.

Landi, P., A. Vicari, and P. Catizone. 1989. Response of maize (Zea mays L.) inbred lines and hybrids to chlorsulfuron. Weed Res. 29:265-271.

Lee, D.L., M.P. Prisbylla, T.H. Cromartie, D.P. Dagarin, S.W. Howard, W.M. Provan, M.K. Ellis, T. Fraser, and L.C. Mutter. 1997. The discovery of the structural requirements of inhibitors of p-hydroxyphenylpyruvate dioxygenase. Weed Sci. 45:601-609.

Masiunas, J., J. Pataky, C. Sprague, M. Williams, and L. Wax. 2004. Sweet corn cultivar tolerance to mesotrione. Weed Sci. Soc. Amer. Abstr. 44:58.

Mitchell, G., D.W. Bartlett, T.E.M. Fraser, T.R. Hawkes, D.C. Holt, J.K. Townson, and R.A. Wichert. 2001. Mesotrione: A new selective herbicide for use in maize. Pest Mgt. Sci. $57: 120-128$.

Moreno, O.J., M.S. Kang, G. Wang, and N. Aminha. 1999. Chromosomal location of $n f s 1$ gene in maize by use of B-A translocations. Abstr. Amer. Soc. Agron. 91:75.

Morton, C.A. and R.G. Harvey. 1992. Sweet corn (Zea mays) hybrid tolerance to nicosulfuron. Weed Technol. 6:91-96.

O'Sullivan, J. and W.J. Bouw. 1998. Sensitivity of processing sweet corn (Zea mays) cultivars to nicosulfuron/rimsulfuron. Can. J. Plant Sci. 78:151-154.

O’Sullivan, J., R.A. Brammall, and W.J. Bouw. 1995. Response of sweet corn (Zea mays) cultivars to nicosulfuron plus rimsulfuron. Weed Technol. 9:58-62.

O'Sullivan, J., P.H. Sikkema, and W.J. Bouw. 2000 Sweet corn (Zea mays) cultivar tolerance to nicosulfuron. Can. J. Plant Sci. 80:419-423.

O'Sullivan, J., J. Zandstra, and P. Sikkema. 2002. Sweet corn (Zea mays) cultivar sensitivity to mesotrione. Weed Technol. 16:421-425.
Pallett, K.E. 2000. The mode of action of isoxaflutole: A case study of an emerging target site, $\mathrm{p}$. 215-238. In: A.H. Cobb and R.C. Kirkwood (eds.). Herbicides and their mechanisms of action. CRC Press, Boca Raton, Fla.

Ray, T.B. 1984. Site of action of chlorsulfuron: inhibition of valine and isoleucine biosynthesis in plants. Plant Physiol. 75:827-831.

Robinson, D.K., D.W. Monks, and J.R. Schulthies. 1994. Effect of nicosulfuron applied postemergence and post-directed on sweet corn (Zea mays) tolerance. Weed Technol. 8:630-634.

Rowe, L., E. Rossman, and D. Penner. 1990. Differential responses of corn hybrids and inbreds to metolachlor. Weed Sci. 38:563-566.

Stall, W.M. and T.A. Bewick. 1992. Sweet corn cultivars respond differently to the herbicide nicosulfuron. HortScience 27:131-133.

Sutton, P., C. Richards, L. Buren, and L. Glasgow. 2002. Activity of mesotrione on resistant weeds in maize. Pest Mgt. Sci. 58:981-984.

Sweetser, P.B., G.S. Schow, and J.M. Hutchinson. 1982. Metabolism of chlorsulfuron by plants: biological basis for selectivity of a new herbicide for cereals. Pest. Biochem. Physiol. 17:18-23.

Wichert, R.A., J.K. Towson, D.W. Bartlett, and G.A. Foxon. 1999. Technical review of mesotrione, a new maize herbicide. Proc. Brighton Crop Prot. Conf.-Weeds 1:105-110.

Widstrom, N.W. and C.C. Dowler. 1995. Sensitivity of selected field corn inbreds (Zea mays) to nicosulfuron. Weed Technol. 9:779-782. 